\title{
Efektifitas Minuman Bekatul Terhadap Kadar LDL dan HDL Siswa Sekolah Dasar Yang Obesitas
}

\author{
Abdul Azis Akbar ${ }^{1}$ \\ ${ }^{1}$ Program studi S1 Gizi, Fakultas Kesehatan masyarakat, Universitas Jember, Indonesia

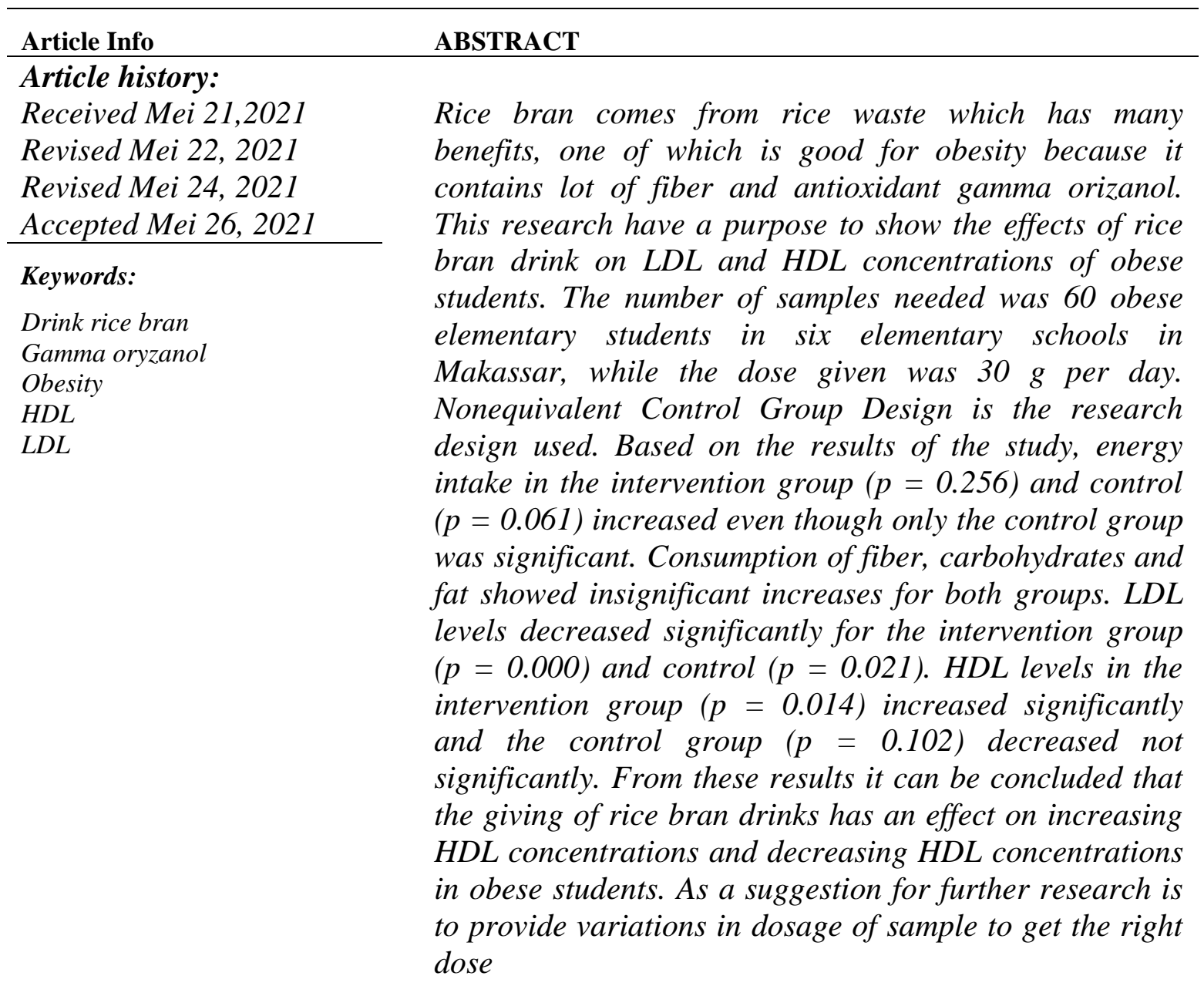

Corresponding Author:

Abdul Azis Akbar,

Program studi S1 Gizi, Fakultas Kesehatan Masyarakat Jember University,

Jl. Diponegoro, Poncogati, Curah Dami, Kabupaten Bondowoso, Jawa Timur 68251, Indonesia

Email: asis.akbar@gmail.com

Journal homepage: https://journal.lppm-unasman.ac.id/index.php/jikm/index 


\section{PENDAHULUAN}

Obesitas mengacu pada keberadaan lemak di tubuh yang sangat berlebih dan menjadi penyakit kronis kompleks yang dapat meningkatkan risiko komplikasi medis jangka panjang [1-2]. Obesitas dapat menjadi penyebab penyakit degeneratif seperti stroke, jantung coroner, kanker [4] seperti kanker payudara, endometrium, ovarium, serviks [5] dan bahkan Corona Virus Diseases atau COVID-19 [6]. Hal ini disebabkan karena adanya peningkatan kadar kolestrol tidak baik atau LDL dan trigliserida meningkat dan kolestrol baik atau HDL menurun pada penderita obesitas [4]. World Health Organization mengemukakan orang dewasa yang mengalami obesitas hampi 2 miliar ditahun 2016, dengan 650 juta di antaranya gemuk. Kenaikan kasus ini hampir 3 kali lebih besar terjadi dari tahun 1970-an dan 2016, dengan kenaikan paling banyak negara berpenghasilan rendah dan negara berpenghasilan menengah [7]. Riset Kesehatan dasar (Riskesdas) tahun 2018 memberikan informasi bahwa pada anak yang berumur di atas 15 tahun menunjukkan terjadinya peningkatan prevalensi obesitas yaitu tahun 2007 sebesar 18,8\%, 2013 sebesar 26,6\% dan 2018 menjadi 31,0\% [8]. Di provinsi Sulawesi Selatan, prevalensi obesitas pada anak yang berumur 15 tahun keatas menunjukkan angka 32\% sedangkan di kota Makassar berada pada 37,3\% di tahun 2018 [9]. Hal ini menunjukkan bahwa kasus obesitas dari tahun ketahun terjadi peningkatan yang sangat mengkhawatirkan, tidak hanya di level daerah tetapi juga di level nasional.

Obesitas pada anak dapat menjadi faktor resiko pada berbagai macam penyakit seperti kelainan jantung, asma, penyumbatan pembuluh darah, diabetes mellitus 2, masalah hati, dislipidemia, dan penyakit akibat sindrom metabolik lainnya [10-11]. Selain itu, obesitas juga dapat mempengaruhi kesehatan fisik, mental dan psikososial anak [12]. Obesitas pada masa anak terbukti merupakan faktor yang menurunkan usia harapan hidup di banyak negara maju. Hasil penelitian menunjukkan orang yang mengalami obesitas dan ganguan pada kesehatan jantung setelah dewasa merupakan akibat dari masa kanak-kanak yang telah mengalami obesitas [13]. Di negara maju, masalah obesitas yang terjadi pada anak dapat meningkatkan angka kematian di Negara tersebut. Seseorang yang berumur sekitar 50 tahun, akan mengalami kematian lebih besar 2 kali lipat ketika saat kecil sudah mengalami obesitas jika dibandingkan tidak mengalami obesitas [14].

Banyak faktor yang dapat mempengaruhi penambahan jumlah obesitas baik faktor eksternal maupun internal. Diantara faktor eksternal yaitu berupa kurangnya olahraga, sering konsumsi junk food, kurang konsumsi sayur dan buah, life style yang salah dan kondisi sosial ekonomi sedangkan faktor internal meliputi faktor jenis kelamin, genetik, usia dan pengaruh psikologis [15]. Tidak seimbangnya energi yang masuk ke tubuh dengan energi yang keluar merupakan faktor terpenting penyebab obesitas [16]. Selain itu, masih banyak anak-anak secara nasional yang berumur 10 tahun belum memahami mengenai pentingnya konsumsi sayur dan buah. Di dalam sayur dan buah terkandung serat dan antioksidan yang baik untuk kesehatan tubuh khususnya penderita obesitas. Kebutuhan serat pada anak yang berumur 10 sampai 12 tahun sekita 28-30 g per harinya [17]. Hal ini mengakibatkan kebutuhan serat dan antioksidan dari sayur dan buah pada anak menjadi tidak terpenuhi.

Bekatul merupakan salah satu pangan fungsional yang baik untuk penderita obesitas [18]. Bekatul dapat diperoleh dari pengolahan padi bersama beras dan dedak. Dedak berasal dari lapisan paling luar padi sedangkan bekatul berasal dari lapisan tengah yang meliputi lapisan aleuron, nucleus, pericarp dan testa pada padi. Lapisan tersebut mengandung banyak senyawa bioaktif khususnya gamma oryzanol [19]. Gamma oryzanol hanya terdapat pada minyak bekatul dan merupakan senyawa bioaktif yang memiliki 
fungsi sebagai antioksidan yang kuat menangkal radikal bebas bahkan jika dibandingkan dengan vitamin $\mathrm{E}$ (tocopherol). Antioksidan ini mengandung ester firulat dan alkohol triterpene. Di dalam minyak bekatul terdapat sekitar 2\% gamma oryzanol. Dengan jumlah tersebut, maka masalah kolestrol yang ada dalam tubuh dipercaya dapat diturunkan oleh gamma oryzanola [20].

Sangat disayangkan jika banyak masyarakat Indonesia yang hanya memanfaatkan bekatul untuk diberikan kepada ternaknya sebagai makanan hanya karena keterbatasan informasi. Padahal banyak sekali produk olahan yang bisa dihasilkan dari bekatul khususnya produk makanan dan. Produk olahan bekatul dapat menghasilkan nilai ekonomi yang sangat tinggi karena selain mudah diperoleh juga mengandung zat gizi yang baik untuk tubuh [19]. Badan Pusat statistik merilis bahwa pada tahun 2019 telah menghasilkan 54,6 juta ton gabah kering giling (GKG). Jumlah ini tentunya sangat banyak dan dimanfaatkan dengan baik untuk kepentingan masyarakat. Jumlah bekatul yang dapat diperoleh dari penggilingan padi yaitu sekitar $10 \%$ dari jumlah produksi gabah, sehingga dapat diprediksi akan menghasilkan jumlah bekatul sebanyak 5,46 juta ton. Oleh sebab itu, penelitian dan pemanfaatan mengenai bekatul perlu ditingkatkan untuk memperoleh manfaat yang luar biasa bagi masyarakat.

Tujuan dari penelitian ini adalah untuk menunjukkan efektifitas minuman dari bekatul terhadap konsentrasi HDL dan LDL siswa sekolah dasar yang mengalami obesitas.

\section{METODE PENELITIAN}

Penelitian ini dilaksanakan di sekolah dasar negeri yang terletak di dua kelurahan yaitu kelurahan Parangtambung dan kelurahan Mangasa yang ada di wilayah kota Makassar. Sekolah dasar negeri tersebut meliputi yaitu SD Inpres Malengkeri Bertingkat 1 dan 2, SDN Parangtambung 1 dan 2, SDN Malengkeri 1 dan 2. Jumlah responden yang dilibatkan dalam penelitian adalah 60 siswa siswi berumur 10 sampai 12 tahun yang memenuhi persyaratan yaitu siswa siswi yang mengalami obesitas, mengisi informed consent yang telah disediakan dengan sadar tanpa paksaan dan selama 2 bulan mampu mengonsumsi serta menghabiskan minuman bekatul yang diberikan. Quasi eksperimen adalah jenis penelitiannya sedangkan Nonequivalent Control Group Design adalah desain penelitian yang digunakan. Variabel penelitian yang ingin diketahui yaitu konsentrasi HDL dan LDL pada responden sebelum dan sesudah intervensi dilaksanakan. Dari total 60 responden akan dibagi menjadi 2 kelompok yaitu kelompok intervensi dan kontrol masing-masing 30 responden.

Di awal penelitian dilaksanakan wawancara dengan memakai kuesioner berisi pertanyaan yang telah diatur sebelumnya untuk memeperoleh informasi data responden. Instrumen lain yang digunakan dalam penelitian yaitu Food Recall 24 jam, Food Frekuensi, timbangan digital, microtoice dan paket alat pengukur HDL dan LDL. Selanjutnya informasi yang dibutuhkan berupa data responden, dilaksanakan 2 kali yaitu sebelum dan setelah intervensi dilaksanakan sedangkan informasi mengenai asupan makanan dan data antropometri diukur 2 kali tiap bulan.

Jenis bekatul yang diolah menjadi produk minuman dalam penelitian ini diperoleh dari tempat penggilingan padi di daerah Sungguminasa, Gowa. Bekatul tersebut selanjutnya diolah dengan alat yang tersedia di laboratorium pengolahan makanan (kuliner) program studi Ilmu Gizi FKM Universitas Hasanuddin untuk diolah menjadi produk minuman berbahan dasar bekatul. Semua informasi yang telah diperoleh selama penelitian berlangsung akan diolah dengan menggunakan aplikasi Wi-Food dan SPSS. Untuk mengetahui kenormalan distribusi responden menggunakan analisis univariat, jika 
distribusi data responden normal akan menggunakan uji t berpasangan (paired t-test) sedangkan jika sebaliknya menggunakan uji wilcoxon. Untuk mengetahui hubungan pada setiap kelompok sebelum dan setelah intervensi menggunakan analisis bivariat, jika distribusi datanya normal akan menggunakan uji t tidak berpasangan (independent t-test) dan jika sebaliknya akan menggunakan uji mann u-whitney.

\section{HASIL DAN PEMBAHASAN}

\subsection{Asupan zat gizi}

Gambaran nutrisi responden pada kedua kelompok memperlihatkan bahwa pola distribusi datanya bersifat homogen karena hasil pengolahan statistik memperlihatkan perbedaan yang tidak signifikan seperti yang terdapat pada tabel 1

Tabel 1. Analisis konsumsi responden sebelum dan sesudah intervensi berdasarkan kelompok

\begin{tabular}{cccccc}
\hline Pemeriksaan & \multicolumn{2}{c}{ Intervensi (n=29) } & \multicolumn{2}{c}{ Kontrol (n=22) } & \multirow{2}{*}{ P Value } \\
\cline { 2 - 5 } Energi (kkal) & Mean & SD & Mean & SD & \multirow{2}{*}{0.518} \\
Energi (\%) & 88.95 & 14.35 & 92.33 & 13.94 & 0.413 \\
Karbohidrat & 263.84 & 40.64 & 260.29 & 51.75 & 0.704 \\
(gr) & & & & & \\
Karbohidrat & 93.44 & 15.01 & 92.94 & 18.55 & 0.827 \\
(\%) & & & & & \\
Lemak (gr) & 53.29 & 23.54 & 60.71 & 24.27 & 0.287 \\
Lemak (\%) & 77.76 & 34.70 & 88.92 & 35.95 & 0.309 \\
Protein (gr) & 61.60 & 20.10 & 61.00 & 12.28 & 0.819 \\
Protein (\%) & 106.55 & 34.17 & 104.40 & 21.52 & 0.842 \\
Serat (gr) & 7.24 & 2.32 & 6.99 & 2.31 & 0.977 \\
\hline Serat (\%) & 24.30 & 7.85 & 24.61 & 7.87 & 0.594 \\
\hline Kolesterol (mg) & 262.76 & 162.74 & 296.57 & 182.78 & 0.581 \\
\hline
\end{tabular}

\subsection{Analisis Bivariat}

Pada Tabel 2 dapat dilihat bahwa terjadi peningkatan konsumsi energi pada kelompok intervensi $(\mathrm{p}=0.256)$ dan kontrol $(\mathrm{p}=0,061)$ walaupun tidak bermakna sedangkan perbedaan konsumsi energinya juga tidak bermakna $(\mathrm{p}=0,761)$. Konsumsi protein kelompok kontrol $(\mathrm{p}=0.472)$ dan intervensi $(\mathrm{p}=0.779)$ mengalami penurunan namun tidak bermakna sedangkan perbedaan konsumsi proteinnya juga tidak bermakna $(\mathrm{p}=0,827)$. Konsumsi lipid kelompok kontrol $(\mathrm{p}=0,823)$ dan intervensi $(\mathrm{p}=0.210)$ mengalami penurunan namun tidak bermakna sedangkan perbedaan asupan lipidnya juga tidak bermakna $(\mathrm{p}=0.648)$. Pada konsumsi karbohidrat kelompok intervensi $(\mathrm{p}=0,144)$ meningkat tidak berarti sebaliknya kelompok kontrol $(\mathrm{p}=0,018)$ meningkat bermakna. Jurnal Kesehatan Masyarakat, Vol. 07, No. 1, 2021: 21-29 
Perbedaan konsumsi karbohidratnya juga tidak bermakna $(\mathrm{p}=0.588)$. Pada konsumsi serat kelompok intervensi $(\mathrm{p}=0,000)$ meningkat bermakna sebaliknya kelompok kontrol $(p=0,107)$ meningkat tidak bermakna. Perbedaan konsumsi seratnya bermakna $(p=0.000)$. Konsumsi kolestrol kedua kelompok baik intervensi $(\mathrm{p}=0.362)$ maupun kontrol $(\mathrm{p}=0.571)$ mengalami peningkatan tidak bermakna sedangkan perbedaan konsumsi kolestrolnya juga tidak bermakna $(\mathrm{p}=0,939)$.

Tabel 2. Hasil penilaian konsumsi makanan sebelum dan sesudah perlakuan berdasarkan kelompok intervensi dan kontrol

\begin{tabular}{|c|c|c|c|c|c|c|c|}
\hline \multirow[t]{2}{*}{ Variabel } & \multicolumn{2}{|c|}{$\begin{array}{l}\text { Kelompok } \\
\text { Intervensi }\end{array}$} & \multirow[t]{2}{*}{$\begin{array}{c}\mathbf{P} \\
\text { value }\end{array}$} & \multicolumn{2}{|c|}{ Kelompok Kontrol } & \multirow[t]{2}{*}{$\begin{array}{c}\mathbf{P} \\
\text { value }\end{array}$} & \multirow{2}{*}{$\begin{array}{c}\text { P value } \\
\text { (inter- } \\
\text { vensi- } \\
\text { kontrol) }\end{array}$} \\
\hline & Pre test & $\begin{array}{l}\text { Post } \\
\text { Test }\end{array}$ & & Pre Test & Post Test & & \\
\hline $\begin{array}{c}\text { Energi } \\
\text { (kkal) }\end{array}$ & $\begin{array}{c}1825.36 \\
\pm \\
277.65\end{array}$ & $\begin{array}{c}1941.43 \\
\pm \\
358.27\end{array}$ & 0.256 & $\begin{array}{c}1880.98 \pm \\
288.96\end{array}$ & $\begin{array}{c}1955.34 \pm \\
344.36\end{array}$ & 0.061 & 0.761 \\
\hline $\begin{array}{l}\text { Protein } \\
\text { (gr) }\end{array}$ & $\begin{array}{c}61.60 \pm \\
20.10\end{array}$ & $\begin{array}{c}59.33 \pm \\
16.22\end{array}$ & 0.779 & $\begin{array}{c}61.00 \pm \\
12.28\end{array}$ & $\begin{array}{c}59.39 \pm \\
19.20\end{array}$ & 0.472 & 0.827 \\
\hline Lemak (gr) & $\begin{array}{c}53.29 \pm \\
23.54\end{array}$ & $\begin{array}{c}63.44 \pm \\
26.22\end{array}$ & 0.210 & $\begin{array}{c}60.71 \pm \\
24.27\end{array}$ & $\begin{array}{c}64.77 \pm \\
38.44\end{array}$ & 0.823 & 0.648 \\
\hline $\begin{array}{c}\text { Karbohidr } \\
\text { at (gr) }\end{array}$ & $\begin{array}{c}263.84 \pm \\
40.68\end{array}$ & $\begin{array}{c}277.06 \pm \\
56.91\end{array}$ & 0.144 & $\begin{array}{c}260.29 \pm \\
51.75\end{array}$ & $\begin{array}{c}291.78 \pm \\
71.70\end{array}$ & 0.018 & 0.588 \\
\hline $\begin{array}{c}\text { Serat } \\
\text { (g) }\end{array}$ & $\begin{array}{c}7.24 \pm \\
2.32\end{array}$ & $\begin{array}{c}16.14 \pm \\
2.47\end{array}$ & 0.000 & $\begin{array}{c}6.99 \pm \\
2.31\end{array}$ & $\begin{array}{c}7.80 \pm \\
3.03\end{array}$ & 0.107 & 0.000 \\
\hline $\begin{array}{c}\text { Kolesterol } \\
\text { (mg) }\end{array}$ & $\begin{array}{c}262.76 \pm \\
143.24\end{array}$ & $\begin{array}{c}296.80 \pm \\
148.74\end{array}$ & 0.362 & $\begin{array}{c}296.57 \pm 1 \\
82.78\end{array}$ & $\begin{array}{c}310.94 \pm \\
209.34\end{array}$ & 0.571 & 0.939 \\
\hline
\end{tabular}

Pada tabel 3 memperlihatkan data berat badan yang meningkat bermakna pada kedua kelompok yaitu intervensi $(\mathrm{p}=0.005)$ dan kontrol $(\mathrm{p}=0.005)$. Dari pemeriksaan sampel darah responden terjadi peningkatan bermakna konsentrasi HDL untuk kelompok intervensi $(\mathrm{p}=0.014)$ sebaliknya terjadi penurunan tidak bermakna untuk kelompok kontrol $(\mathrm{p}=0.102)$. Untuk konsentrasi LDL untuk kelompok intervensi $(\mathrm{p}=0,000)$ dan kontrol $(\mathrm{p}=0,021)$ terjadi penurunan dan bermakna. 
Tabel 3. Hasil penilaian berat badan dan konsentrasi HDL dan LDL berdasarkan kelompok perlakuan

\begin{tabular}{|c|c|c|c|c|c|c|c|}
\hline \multirow[t]{2}{*}{ Variabel } & \multicolumn{2}{|c|}{$\begin{array}{l}\text { Kelompok } \\
\text { Intervensi }\end{array}$} & \multirow[t]{2}{*}{$\begin{array}{c}\mathbf{P} \\
\text { value }\end{array}$} & \multicolumn{2}{|c|}{ Kelompok Kontrol } & \multirow[t]{2}{*}{$\begin{array}{c}\mathbf{P} \\
\text { value }\end{array}$} & \multirow{2}{*}{$\begin{array}{c}\text { P Value } \\
\text { (Interven } \\
\text { si dan } \\
\text { kontrol) }\end{array}$} \\
\hline & Pre test & $\begin{array}{l}\text { Post } \\
\text { Test }\end{array}$ & & Pre Test & Post Test & & \\
\hline $\begin{array}{c}\text { Berat } \\
\text { Badan } \\
(\mathbf{k g})\end{array}$ & $\begin{array}{c}52.67 \pm \\
9.04\end{array}$ & $\begin{array}{c}53.68 \pm \\
8.87\end{array}$ & 0.005 & $\begin{array}{c}49.86 \pm 9 \\
66\end{array}$ & $\begin{array}{c}50.92 \pm 10 \\
02\end{array}$ & 0.005 & 0.403 \\
\hline $\begin{array}{c}\text { LDL } \\
(\mathrm{mg} / \mathrm{dl})\end{array}$ & $\begin{array}{c}104,66 \pm \\
21,76\end{array}$ & $\begin{array}{c}84,83 \pm 2 \\
2,66\end{array}$ & 0.000 & $\begin{array}{c}105,27 \pm 2 \\
4,01\end{array}$ & $\begin{array}{c}89,41 \pm \\
34,73\end{array}$ & 0.021 & 0,754 \\
\hline $\begin{array}{c}\text { HDL } \\
\text { (mg/dl) }\end{array}$ & $\begin{array}{c}41,69 \pm 1 \\
3,07\end{array}$ & $\begin{array}{c}46,21 \pm 1 \\
0,97\end{array}$ & 0,014 & $\begin{array}{c}53,59 \pm \\
24,86\end{array}$ & $\begin{array}{c}43,73 \pm \\
13,73\end{array}$ & 0,102 & 0,245 \\
\hline
\end{tabular}

\subsection{Pembahasan}

Berdasarkan hasil yang diperoleh dapat diketahui pada pemberian minuman berbahan bekatul memiliki pengaruh bermakna pada peningkatan konsentrasi HDL dan penurunan konsentrasi LDL. Hasil penelitian menjelaskan bahwa terjadi penurunan secara bermakna untuk konsentrasi LDL pada kedua kelompok. Hasil ini diperkuat oleh penelitian sebelumnya yang menjelaskan bahwa senyawa bioaktif gamma oryzanol dalam produk olahan bekatul dapat menekan konsentrasi kolestrol jahat (LDL) dalam darah [22]. Penelitian lain yang dilakukan pada sekelompok hamster [23] dan monyet [24] juga menunjukkan bahwa gamma oryzanol dapat menghambat pembentukan plak pada aorta dan menurunkan penyerapan LDL di saluran pencernaan tubuh karena struktur yang dimiliki kolestrol mirip dengan struktur gamma orizanol [25]. Gamma oryzanol secara struktur tersusun dari asam ferulic pada sejumlah ferulasi fitosteril yang memiliki peranan penting melawan radikal bebas dan penghambatan oksidasi kolestrol [24]. Selain itu, kandungan serat dalam bekatul kemungkinan akan meningkatkan fungsi enzim kolesterol$7 \alpha$-hidroksilase dalam pengurangan kolesterol yang ada di hati. Akibatnya asam empedu yang terbentuk dari proses konversi dari kolestrol akan meningkat, sehingga konsentrasi kolestrol yang ada di dalam darah akan menurun [25]. Hasil lain menunjukkan jumlah konsentrasi HDL yang meningkat pada kelompok intervensi secara bermakna. Hal ini didukung oleh beberapa penelitian pada kelinci, tikus, primata dan manusia yang menunjukkan adanya peningkatan HDL setelah pemberian suplementasi bekatul [24-26]. Hasil tersebut disebabkan karena adanya serat dan senyawa bioaktif gamma orizanol di dalam bekatul [27].

\section{KESIMPULAN}

Kesimpulan dari penelitian ini bahwa pemberian minuman bekatul sangat baik dalam meningkatkan konsentrasi HDL dan menurunkan konsentrasi LDL pada anak yang mengalami obesitas.

\section{UCAPAN TERIMA KASIH}

Peneliti mengucapkan terima kasih kepada pihak prodi Ilmu Gizi FKM Universitas Hasanuddin yang telah bersedia menerima peneliti untuk melakukan pengolahan bekatul Jurnal Kesehatan Masyarakat, Vol. 07, No. 1, 2021: 21-29 
menjadi minuman bekatul di laboratorium kulinari dan pihak prodi S1 Gizi FKM Universitas Jember yang telah memberikan sarana dan prasarana kepada peneliti untuk menyelesaikan penyusunan artikel penelitian ini

\section{DAFTAR PUSTAKA}

[1] Abduelmula R. Abduelkarem. Et al. "Obesity and its associated risk factors among school-aged children in Sharjah, UAE". https://doi.org/10.1371/journal.pone.0234244

[2] Sean Wharton MD, et al. "Obesity in adults: a clinical practice guideline". CMAJ 2020 August 4;192:E875-91.doi: 10.1503/cmaj.191707

[3] Rishi Caleyachetty, et al. "Ethnicity-specific BMI cutoffs for obesity based on type 2 diabetes risk in England: a population-based cohort study". Published online May 11, 2021 www.thelancet.com/diabetes-endocrinology

[4] Praditasari, Jayanti Ayu dan Sri Sumarmi. "Asupan lemak, aktivitas fisik dan kegemukan pada remaja putri di smp bina insani Surabaya. Media Gizi Indonesia, Vol. 13, No. 2 Juli-Desember 2018: hlm. 117-122

[5] Megan A. Clarke. "It's not just size that matters: Challenges in studying obesity and female-specific cancers". The Lancet Regional Health-Western Pacific 11 (2021) 100164

[6] Sattar, et al,. Obesity Is a Risk Factor for Severe COVID-19 Infection. American Heart Association, Inc. 2020. https://www.ahajournals.org/journal/circ

[7] World Health Organization. "The prevalence of obesity". https://www.who. int/news-room/fact-sheets/detail/obesity-and-overweight. 2016

[8] Riset Kesehatan Dasar (Riskesdas) 2018. Badan Penelitian dan Pengembangan Kesehatan Departemen Kesehatan, Republik Indonesia. 2019

[9] Riset Kesehatan Dasar (Riskesdas) 2018 Sulawesi Selatan. Lembaga Penerbit Badan Penelitian dan Pengembangan Kesehatan. 2019

[10]Septiani, Riswanti dan Rahardjo, Bambang Budi. "Pola Konsumsi Fast Food, Aktivitas Fisik dan Faktor Keturunan Terhadap Kejadian Obesitas (Studi Kasus pada Siswa SD Negeri 01 Tonjong Kecamatan Tonjong Kebupaten Brebes)". Public Health Perspective Journal 2 (3) (2017) 262 - 269

[11] Ikatan Dokter Anak Indonesia. "Diagnosis, Tata Laksana dan Pencegahan Obesitas pada Anak dan Remaja". Unit Kerja Koordinasi Nutrisi dan Penyakit Metabolik. 2014

[12] Nudhira Uyunun, Cri SP Wekadigunawan dan Bhisma Murti. "Path Analysis on Life Course Factors Affecting Overweight and Obesity in Children Aged 2 to 5 Years Old in Surakarta". Journal of Epidemiology and Public Health (2017), 2(3): 267-283

[13] Duncan S.,et al., "Modifiable risk factors for overweight and obesity in children and adolescents from São Paulo, Brazil". BioMed Central Public Health 11:585. 2011

[14] Soegih RR., Wiramihardja KK. "Obesitas: Permasalahan dan Terapi Praktis". Jakarta: Sagung Seto. 2009

[15] Kurdanti, Weni, et al,. Faktor-faktor yang mempengaruhi kejadian obesitas pada remaja. Jurnal Gizi Klinik Indonesia Volume 11 No. 04 April. 2015

[16] Ayu, Destya Sekar dan Oktia Woro Kasmini Handayani. "Diary teratas (terapi anak obesitas) dalam perubahan perilaku gizi siswa sekolah dasar". Unnes Journal of Public Health Volume 5 (2). 2016 
[17] Kementrian Kesehatan Republik Indonesia. "Angka Kecukupan Gizi”. Jakarta. 2017

[18] Faizah, Feri Kusnandar dan Siti Nurjannah. "Senyawa fenolik, aryzanol dan senyawa antioksidan bekatul yang difermentasi dengan Rhizopus oryzae". Jurnal Teknologi dan industri pangan volume 31 (1): 86-94 Th. 2020

[19] Purwanto Agus, Astri Nur Fajriyati, dan Dewi Wahyuningtyas. "Pengaruh jenis pelarut terhadap rendemen dan aktivitas antioksidan dalam ekstrak minyak bekatul padi (rice bran oil)". Ekuilibrum Vol. 13. No. 1. Januari 2014 : 29 - 34

[20] Royani Sitti hajar dan Amanda Tiara Putri Widodo. "Ekstraksi oryzanol dari dedak padi dengan air dan etanol subkritis". Jurusan Teknik Kimia Fakultas Teknologi Industri Insitut Teknologi Sepuluh Nopember Surabaya. 2015

[21] Badan Pusat Statistik (BPS). "Luas panen dan produksi padi pada tahun 2019" https://www.bps.go.id/pressrelease/2020/02/04/1752/luas-panen-dan-produksi-padi-pada-tahun-2019mengalami-penurunan-dibandingkan-tahun-2018-masing-masing-sebesar-6-15-dan-7-76-persen.html

[22] Mumpuni, Prapsiwi Dwi. “Analisis kadar tokoferol, gamma oryzanol dan beta karoten serta aktifitas antioksidan minyak bekatul kasar”. Program studi Ilmu Gizi Fakultas Kedokteran Universitas Diponegoro. Semarang. 2013

[23] B.S. Narasinga Rao. "Nutritive Value Of Rice Bran". Ms Bani Tamberfor the Nutrition Foundation of India, C-13 Qutab Institutional Area, New Delhi 110016

[24] Md Safiqul Islam, et al,. Rice Bran Antioxidants in Health and Wellness. Wheat and Rice in Disease Prevention and Health http://dx.doi.org/10.1016/B978-0-12-401716-0.000349. 2014

[25] Nur Nashriana J, Bambang Wirjatmadi, Merryana Adriani. "Combined Food (Rice Bran and Fat) Reduce of the Total Cholesterol Levels, Triglycerides, and LDL of Wistar Strain Rats". Jurnal Kedokteran Brawijaya, Vol. 28, No. 3, Februari 2015

[26] Wilson TA, Nicolosi RJ, Woolfrey B, and Kritchevsky D. "Rice Bran Oil and Oryzanol Reduce Plasma Lipid, Lipoprotein Cholesterol Concentrations and Aortic Cholesterol Ester Accumulation to a Greater Extent than Ferulic Acid in Hypercholesterolemic Hamsters". The Journal of Nutritional Biochemistry. 2007; 18(2): 40-43. 105-120.

[27] Indra, Ignatius Roy dan Binar Panunggal. "Pengaruh pemberian selai kacang tanah dengan substitusi bekatul terhadap kadar kolesterol ldl dan hdl tikus hiperkolesterolemia". Journal of Nutrition College, Volume 4, Nomor 2, Tahun 2015, Halaman 171-179 